\title{
MUHAMMAD HASAN ASKARI
}

\section{Literature and Revolution*}

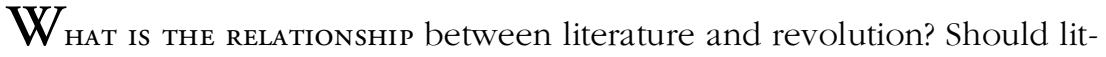
erature assist revolution and, if so, to what degree? Before deliberating on these questions we should first determine the precise meaning of the term "revolution," because many champions of revolution are found to be generally unaware of what the term implies and what we ourselves understand it to mean. A host of problems arise from the lack of a proper understanding of the word, whether in literature or in politics. A further difficulty is that, like all other terms, the meaning is not determined so much by an individual's sense-experiences as by the requirements, and sometimes even the convenience, of parties founded on political and sociological beliefs. In any case, an exploration of the word "revolution" reveals several meanings.

I. We first encounter a common man's concept of revolution. Since some degree of force generally accompanies every revolutionary act, an individual witnesses some bloodletting, mayhem and plunder. All nations experience such things on a large or small scale. As a result, the instant the word "revolution" is mentioned, the mind inevitably conjures up images of bloodshed and carnage. Rulers, whether individuals or groups, usually do not relinquish power easily, they have to be forced out, so revolutionary groups themselves encourage this concept of revolution. The fact that the concept becomes a noose around their own necks after the revolution is over is another matter. At least until it is accomplished, they propagate, directly or by deliberate oversight, this concept among the masses in order to prime them for the exercise of force. Then too, the atmosphere of political and economic repression pervading the prerevolutionary period predisposes human nature to violence. As they raise the cry "Long Live the Revolution!" the thought uppermost in the minds of

" "Adab aur Inqilāb," from Muhammad Hasan 'Askarī, Insān aur Ādmì (Aligarh: Educational Book House, I976), III-I9.

All notes and full names and dates of authors added by the translator. 
the participants or merely the supporters of a revolution is not that their action will make them the rulers, but rather that it will give them the chance to annihilate the present rulers. Such a concept of revolution is not limited just to the masses; even otherwise peace-loving people in ordinary circumstances become affected by it, never mind creative writers who are only too quick to be swept up by it because they have a close affinity to the subliminal urges of their time. Even Percy Bysshe Shelley (I792-I822), otherwise given to counsel revolutionaries to fight tyranny with peaceful means, normally cannot talk about revolution without its attendant killing and destruction. While it is true that a revolution requiring the slaughter of humans depresses him, he is not one to hold back on savoring the sight of bloodshed and mayhem. Indeed, the balance of all European revolutionary poetry after the French Revolution is filled with accounts of bloodshed, and even revolutionary poems composed under the strict influence of pure Marxism are not void of it, so much so that one sees it even in the poems of such reflective poets as Cecil Day Lewis (1904-1972), Stephen Spender (1909-1995), and W. H. Auden (1907-1973). In Urdu too, the situation is not much different. Just think of the political poems written until ten years ago: how often the words "dagger," "sword," "fire" and "blood" appear in them! And in one poem by Ehsan Danish (1915-1982) all limits are crossed, the poem in which the poet dreams about revolution. A similar tendency is seen in art as well, the best example being the work of Eugène Delacroix (1798-I863). He is unable to keep carnage and revolution apart even for an instant. In short, we can easily fill hundreds of pages with examples from literature of this concept of revolution.

But can such literature offer any grand observation? Even Marxists would refuse to accept that. Literature is essentially the search for a new balance, while this concept of revolution leaves absolutely no room for balance. The reason literature strives for balance is that literature basically upholds creation and what is positive, whereas the aforementioned concept represents destruction for its own sake, a concept that trounces everything else. So while it can create effective literature, it cannot produce great literature. Generally on such occasions the result sounds more like oratory than literature. Once the revolutionary period has ended, this material begins to appear quite insipid, hollow, and, at times, even ridiculous. William Butler Yates (I865-I939) has said that poetry is born when a man fights with himself and oratory when he fights with others. In the kind of revolutionary poetry we are talking about, the battle is not against the spirits or principles of others, it is with others as mere objects -objects we are hell-bent on blowing to bits. And what you want to 
destroy, your attitude regarding that object can never be creative. As long as you are determined to destroy certain objects (not humans or principles but objects) solely for the sake of destroying them, you cannot create great literature. Such an attitude is altogether inhumane, and after losing his humanity a person simply cannot create anything worthwhile in human terms. One thing, however, is possible: it is likely that the impulse merely to destroy may gradually turn into a desire to observe destruction objectively or with curiosity, resulting in the production of an impressive portrayal of it. In this case, it is entirely within reach to produce truly great literature and art. Again, Delacroix offers the best examples of this kind of art. But, at any rate, this is only possible after the revolution, not before, especially for an artist who wants to support the revolutionary action and is also obsessed with bloodshed.

The personality of an artist whose mind is taken over by revolutionary bloodshed should not be considered free of sexual complexities. Here I am reminded of a canvas of Delacroix, Liberty Leading the People, in which the psychological biography of not only the painter but of all revolutionary artists like him is tellingly revealed. Goddess Liberty is here depicted as a fabulously large-bosomed, fantastically robust woman. She is the focal point of the painter's attention, but he lacks the inner strength to subdue such an immense woman physically. Hence his frustration and unrequited desire turns into sadism and masochism. He cannot imagine such a woman without piles of dead or wounded bodies. If such an artist also happens to be interested in politics, he immediately becomes a devotee of revolutionary carnage. It is true that this type of sexual complexity does tend to blunt the severity of political destruction for its own sake, and the encroachment of psychological problems on his creation saves it from degenerating into non-literature and non-art. Hence sexual complexity has both good and bad aspects, otherwise Delacroix's paintings would never have been so successful.

2. The second meaning of revolution is comparatively more profound. The more astute among the revolutionaries are aware of this meaning from early on. Others also come to it eventually, but only after the revolution, or they are so taken up with their ordinary affairs that they forget about the revolution altogether. Bloodshed and destruction is not the true meaning of revolution, nor is revolution just any kind of change. This would be its cheapest, tritest meaning. True revolution can happen without spilling a single drop of blood, although blood does spill. The true meaning of revolution is that the old order of life, which no longer serves any purpose, should change, replaced by a new order that is more in consonance with the new conditions. True revolution does not just 
imply political or economic change; first and foremost it is a change in the system of values-a change not just in society's external structure but also in its heart and mind and everything else. True revolution is psychological. It gives birth to a new man. (Of course, I am using "new" in a very restricted sense.) Literature always facilitates the occurrence of this revolution. Indeed, it walks well ahead of it and suggests when basic changes are due. And it is literature again that articulates the psychological aspects of these changes. Without calling itself overtly revolutionary, literature is the herald of every major and fundamental revolution. D. H. Lawrence (I885-1930) even goes so far as to declare that unless and until a writer portrays the basic changes in man's consciousness, he cannot become a great writer. Although disenchanted with politics, Lawrence admits that Shakespeare's greatness lies in his portrayal of some basic changes that took place in the political consciousness of man. Personally, I do not fully accept this characterization of Shakespeare. Nonetheless, I do feel that basically Lawrence is right. And it is not just Shakespeare, traces of changes in consciousness and of revolutions are found even in James Joyce (I882-194I), and we would be right in calling him a revolutionary writer.

Let's not expand the meaning of revolution too much but rather keep it confined to political and economic change because it is these changes that man often considers most needed and which manifest themselves most prominently. When such changes are called for, literature always supports them, it being of no consequence if a few or even a dozen writers oppose them. As a whole literature favors such changes because it is the instrument through which a nation articulates a new balance. As such, literature's support for changes is inevitable. This has been an enduring norm of life. It cannot be denied, however, that a substantial amount of retrogressive thinking is also found in writers. An author, after all, can only write about what he has experienced through his senses and his mind, and such things only obtain during a specific time. He cannot write about what does not exist or what may exist in a future time because these fall outside the orbit of his experience. This fact leads him to support the continuation of existing things. This aspect of a writer is nonrevolutionary and, to a degree, immutable. But it is also true that when conditions force man to change, literature chimes in with the conditions.

Literature that points to changes is of two kinds. One group of writers shows variously why the old system and values are insufficient and unworkable. Often such writers are devotedly in love with what is old and are loath to change it, but their spirit of objectivity compels them to see their uselessness. Even such writers serve the cause of revolution. Their creative work is not characterized by destruction for its own sake, but 
rather destruction for the sake of construction.

The second group consists of writers who know at a conscious level what new values need to replace the old ones. At least they point, even if unconsciously, in the direction of new values. These are the true revolutionary writers, whether or not they display a penchant for violence. Even if one is not inclined to label them revolutionary, the fact is that revolution cannot come about without them, at least from a psychological perspective.

Like other literatures, Urdu literature has always supported these kinds of revolutionary changes, and by that I mean changes that occur in the consciousness of man. Sir Syed's (I817-1898) movement also had a few revolutionary elements, even if it apparently seemed to be entirely reformist. At any rate, literature participated equally in the changes this movement wrought in the consciousness of Muslims; rather, those changes were accomplished to a large extent through literature. It was not until around 1936 that our consciousness felt once again the need to change its course. At that time, too, our literature had on the whole outpaced the politics of the time in this psychological revolution. These psychological changes were accomplished not only with the help of those writers who consciously favored a revolution in the domain of values, but also to a large extent by writers who very consciously strove to keep literature far away from any kind of revolutionary demands. These writers actually carried the spirit of revolution far beyond politics and economics into the smallest areas of life.

3. So these are the two major meanings of the word "revolution." However, there are times when its meaning also changes according to the convenience of political groups. In discussing the relationship between literature and revolution, the French philosopher Jean-Paul Sartre (1905I980) offers two recent examples of this phenomenon. During the German occupation of France many politically minded people collaborated with the Germans. One such individual reasoned: in view of the country's current situation, revolution means that everything should be left as it is. The second definition came from a Communist. For him revolution meant an increase in production. Both definitions make the very concept of revolution stand on its head. One can accept that revolution is not needed all the time. Once the old system of values comes to an end, it becomes incumbent that destructive actions are halted and new values are given a firm grounding, but this process cannot be called "revolution," and it is this that is needed. The problem is, "revolution" is a very attractive word. It stirs up excitement in whoever hears it. Political parties need this excitement to enlist more supporters. How can they ever abandon using it? Since 
a new group on the seat of power follows a revolution, the true meaning of "revolution" goes against the interests of this newly emergent group. On the other hand, they need to use it in order to promote their interests. Eventually, they transform its meaning. It no longer denotes "change," but "preservation." Such is the accomplishment of our twentieth-century politics. Such deceptions are nothing new. They have always been there, but people didn't always know how to distort so easily.

Literature assists revolution only when life itself perceives the need for it. The aforementioned "revolution" is an altogether absurd term; literature cannot go along with it. If you tell a writer that the need for revolution has run its course, he will accept it. But if you solicit his assistance by calling a non-revolutionary process a revolution, his senses will refuse to accept this meaning. It is a different matter that the litterateurs of a country have become slaves of their politicians to such a degree that they accept what is handed to them without the slightest hesitation. But to accept an interpretation of reality that goes counter to your own sense perceptions means that you simply cannot create any worthwhile literature. This is precisely what is happening in Russia these days.

All of the above meanings of "revolution" are more or less political. Since the word is mostly used with regard to political and economic institutions, it has become the plaything of political parties. These parties also expect writers to accept only the concept of revolution that they themselves prefer to float. But why should literature accept such a limitation? Revolution is not merely a political thing. It is a psychological more than a political, phenomenon. Why shouldn't we keep the more expansive meaning of revolution in mind when we talk about literature? If revolution means the ability to change oneself in order to harmonize with new conditions, then the need for such harmonizing can occur at any moment in even the smallest area of life, and literature generally portrays such moments. Harmonization with the demands of reality is in itself a continuous revolution. Literature primarily reflects this revolution; in fact this revolution is necessary for the preservation of mankind. The revolutionary action of literature lies in its ability to bring about accord with reality, and it achieves this accord by transforming, within suitable limits, the conditions of life along with the changing forms of reality. Dialectical action does not occur only at the political and economic levels of life. There are any number of areas where a dialectical process takes place. Literature is comprised of every major and minor manifestation of the dialectical process. Take these famous lines of Mìr:

faqīrāna à'ē șadā kar čalē

miyāñ khush rahō ham du'ā kar čalē 
I56 - The Annual of Urdu Studies, No. 25

A beggar I came and cried my say:

"May you live happy, and happy stay."

Is there less dialectics in these lines? True dialectics is nothing other than what is found in ordinary human relationships. Is there any less revolution-psychological and ethical-lying concealed in the following lines of Mìr?:

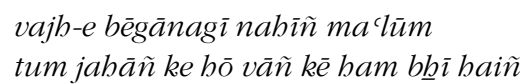

I cannot see why you should act the stranger,

For you and I spring from a common source. ${ }^{2}$

If only people could understand the dialectics in these lines of Mirr, the consequent revolution such an understanding would unleash would be far greater than that of Marx. It is true, a majority of people cannot fathom such dialectics and, therefore, the revolution conceived by Mir will never come about. But what is the function of literature if not to offer mankind ever newer forms of revolution and expand and deepen the meaning of the term. Only a great writer is truly a great revolutionary.

- Translated by Mubammad Umar Memon

${ }^{1}$ Translation by Ahmed Ali in his The Golden Tradition: An Anthology of Urdu Poetry (New York: Columbia University Press, 1973), I73.

${ }^{2}$ Translation by Ralph Russell and Khurshidul Islam in their Three Mughal Poets: Mir, Sauda, Mir Hasan (Cambridge, MA: Harvard University Press, 1968), 135. 